\title{
Strengthening and Improving Ideological and Political Education in Colleges and Universities under the New Situation
}

\author{
Yuan Gao \\ Ideological and Political Department \\ Zhengzhou University of Aeronautics \\ Zhengzhou, China
}

\begin{abstract}
The preparatory education for ethnic minorities is a great measure of the national policy of the Communist Party of China $^{[1]}$. To cultivate the national preparatory students to establish a correct world outlook, values, and national view, is directly related to national unity and national unity ${ }^{[2]}$. But, at present, many colleges and universities regard the ideological and political education of ethnic minority preparatory course as the same as other basic cultural subjects. They only intend to instill conceptual knowledge to students and only pay attention to the students' test scores. This is fundamentally contrary to the purpose of ideological and political education, and will never achieve the expected effect. Under today's unprecedented social change and technological development, the ideological and political education environment has changed greatly compared with the previous ${ }^{[3]}$. Then, how to improve the ideological and political education of ethnic preparatory students to adapt to the requirements of the new era is very necessary. In this paper, the current situation of ideological and political education of minority preparatory is summarized, the existing problems are analyzed, and some thoughts on the reform and innovation of ideological and political education in Colleges and universities are discussed.
\end{abstract}

Keywords-minority preparatory education; ethnological viewpoint; country view; education reform; invention

\section{INTRODUCTION}

Minority preparatory education is an integral part of higher education with Chinese characteristics, and is an important link to cultivate high-level talents of minority. [4] Many people in the national matriculation will become the backbone of ethnic areas in politics, economy, science and technology in the future They will play an inestimable role in the political stability, economic prosperity and development of ethnic areas. In particular, under the strategy of developing the western region by the State Council, only by strengthening the training of national talents and the development of national education, can we provide the High - quality personnel guarantee for the modernization of ethnic areas, and can we promote the transformation and prosperity of ethnic minority areas, finally, can we eliminate the imbalance between the economic and cultural development of all ethnic groups gradually.

To cultivate the national preparatory students to establish a correct world outlook, values, and national view, is directly related to national unity and national unity. Therefore, it is of great theoretical and practical significance to effectively carry out ideological and political education of ethnic preparatory students ${ }^{[5]}$, to promote the stability and sustainable development of ethnic areas, and to enhance national unity.

In this paper, the current situation of ideological and political education of minority preparatory course is summarized, the existing problems are analyzed, and some thoughts on the reform and innovation of ideological and political education in colleges and universities are discussed.

II. SOME PROBLEMS IN THE PRESENT IDEOLOGICAL AND POLITICAL EDUCATION OF MINORITY PREPARATORY COURSE

Since the reform and opening up in China, the ideological and political education for ethnic minorities has made remarkable achievements, however, especially since the new century, the ideological and political education of ethnic minority preparatory education has exposed many problems, mainly reflected in the following aspects:

\section{A. Ideological and Political Education for Minority}

Preparatory Is Poor in Systematicness ${ }^{[6]}$

For example, its training objectives, teaching plans and other aspects are not standardized and profound. Besides, the content of the textbook is too simplistic and knowledgeable. There is no combination of theory and practice, and there is no pertinence and practicality.

\section{B. Teaching Mode Is Relatively Conservative and Rigid.}

The main style in education is to instill the concept directly to students. Especially under the examination environment, the ideological and political education has become a complete examination and knowledge - oriented subject.

\section{Examination Performance Is the only Way for Assessment.}

Most of colleges and universities in the country regard the test scores as the only standard of evaluation of students ideological level.

\section{Educational Research Ability Is Weak}

In contrast with other knowledge subject, its research quantity and quality are very poor in research production, teaching experiment results and published papers. 
As we all know, the ideological and political education is different from the basic knowledge education. It is the position of cultivating national youth to establish the correct concept of nation, nation, ideal, faith, belief and sense of social responsibility. If the teaching material and the teacher only pay attention to instilling the mainstream political values and the concept of the nation and the religious to students, and only care about the test scores of students, the crash to contemporary ideology from the social and political would be ignored, the psychological characteristics, cognitive rules and ideological needs of contemporary ethnic students would be ignored either. Thus, we cannot really stimulate the recognition about the mainstream moral values, historical and cultural traditions of ethnic minority students, not to mention to provide any guidance and help to their study, life, thought and behavior in current or future. The seriously bad consequence is that, the needs of national construction for national talent could never be met.

Especially with the unprecedented changes in the social and technological development, the ideological and political education environment has undergone great changes. Profound changes have taken place in the economic system and social structure, which results in the uncoordination between superstructure and economic base. [7] The original social morality gradually lost its binding force. The new moral concepts and norms have not yet formed. The behavior of members of society is in a disorder state. Especially with the increasing diversity of social and cultural, and with the rapid development of information technology, a large number of fragmented, massive information provide young students information more widely and convenientely. Unfortunately a large number of negative, incorrect and decadent ideas blow up meanwhile, which conflict seriously with the well-integrated value system, ideology and morality propagated by ideological and political workers, and badly affected the students' values. In the new period, although the basic level of thinking and understanding of ethnic preparatory students is relatively high, but because of their world outlook, outlook on life, values are not yet mature, [8]and the lack of social life experience, they are more prone to confusion and loss of direction in the face of such confused social environment. This has brought a lot of new contradictions and problems to the ideological and political education. If we cannot grasp the correct orientation of ideological and political education of ethnic preparatory course under the new situation, cannot establish the ideological and political education mode which is suitable for the new situation and still follow the previous teaching model, students will consider the mainstream value view is not only difficult to understand and outdated, and not worth following. A more unfavorable situation is that it will cause serious psychological question, and even with extreme words and deeds from students against the ideological and political education

Therefore, it is very necessary to strengthen and improve the ideological and political education of Ethnic Preparatory Students.

\section{SOME SUGGESTIONS ON STRENGTHENING AND IMPROVING IDEOLOGICAL AND POLITICAL EDUCATION OF ETHNIC MINORITY PREPARATORY COURSE}

The use of new teaching methods such as multimedia or equipped with more advanced teaching equipment, is not a radical reform and innovation to ideological and political education of ethnic preparatory. Innovation does not mean discarding old things, creating something new. To transform an angle to analyze and solve problems is a kind of innovation, in my own opinion. Combined with my teaching practice, this paper discusses the reform and innovation of ideological and political education in colleges and universities from the following five aspects:

\section{A. Clear and Correct the Education Objective to Minority Preparatory Students ${ }^{[3]}$.}

It is to nurture qualified persons of the state who are agree with the mainstream political ideas in thinking and implement mainstream behavior norms in doing. This requires us respect and pay attention to the value of the individual life of the students and to make them understand that the existence of the individual is to seek development by adjusting themselves to adapt to the early stereotypes of the group based on the mode of life. Morever, we should intend to help them establish the beliefs that the well-integrated values, outlook on nation and religion would lead them success and happiness. So that they could actively deal with the ideological and political courses.

\section{B. Understanding the New Features of the Contemporary}

Ethnic Students, Keeping up with the Ideological Trend of

Them and Guiding Them in A Right Way.

Generally speaking, the preparatory students of the new era have a higher thinking flexibility, and have a strong sense of self-consciousness but weak self-control. In the era of information explosion, the operation of information communication platform is simplified, which makes it difficult to identify good news from bad ones, and difficult to control the public opinion guidance. Thus, the negative content such as pragmatism, hedonism, individualism, money worship and so on have seriously impacted and influenced their concept values, and challenged their moral values and behavior norms. At the same time, the traditional culture and modern culture, native culture and exotic culture intertwined with each other, the western ideology constantly infiltrated, etc. All these not only affect the students' evaluation of the original value, made them puzzled and confused, but also brought a lot of opportunities and challenges to the ideological and political education. [9] Only by accurately grasping the ideological trend of ethnic preparatory students, and fully understand the characteristics of the times, can we make the ideological and political education of ethnic preparatory courses targeted.

\section{Reform the Teaching Model.}

Use the existing resource, immerse the ideological and political education into students' daily lives outside the classroom. Allow students to accept the socialist core value system in a subtle way. If ethnic minority preparatory students accept that the mainstream values, outlook on nation and religion would lead them success and happiness, they will use various methods to overcome various obstacles caused by the 
differences in culture and language to complete the learning task of ideological and political course. But if they insist that the ideological and political education system is only a deprivation of their own cultural characteristics and national identity, instead of brought them more opportunities in their future life and work, they will be negative about and resist learning. Most minority preparatory students have their own cultures which are very different from such kind of culture given by the ideological and political education. They have to face up with the conflict between the foreign cultural values and their natural cultural values, and the differences between the ideal values and the actual values. This is called acculturation difficulty.

If teachers want to achieve the effect of classroom teaching strategy, and want to be helpful for cultivating minority preparatory students to love their hometown and nation, and to establish national identity, we should work hard to understand the cultural background of students, to study the learning styles of students of different nationalities, and to reflect on our own teaching style, so that our style could consistent rather than contrary to students' learning style.

All these good ideas need us to respect the students' cognitive rules, to work from the perspective and demand of students, to link Marx doctrine and dialectics of nature to natural science, to excavate the rich resources behind the teaching material, to absorb the views of the relevant science, theory and research results, to improve our teachers' own vision, to break the traditional educational barriers, to pursuit the root and origin of the mainstream political concept, to elaborate the development process of the concept of nation, religion, and the historical links between them, to establish the macro linkages and logical links among various concepts in national theory, to display a more integrated development system of ideological value, to finally let the students really understand and accept the value system. This also requires us to combine the actual social phenomenon with the new features of contemporary ethnic students, to face a variety of value conflicts and confusion along with them, to summarize the experience and lessons in learning and life along with them, to guide and improve the students' practical ability of social life finally.

\section{Reform Evaluation Standard.}

Examination results cannot be the only objective moral evaluation to students. It is suggested that all the contents of the standard education, civilized manners education, discipline education, legal education, environmental education and social practice education should be included in the evaluation of students' ideological and political education.

\section{E. Explore to Establish and Improve the Security Mechanism of National Matriculation Ideological and Political Education, to Retain the Pioneering Spirit.}

- The ideological and political education policy is not strong enough and lacks uniform regulations. For example, its training objectives, teaching plans, teaching materials and other specific aspects of ethnic preparatory courses are not clear, to some extent, it affected the development of ideological and political education. We should formulate and improve the system of national preparatory ideological and political education laws and regulations as soon as possible, so that the management and quality assessment and other aspects could be more standardized.

- Set up the national minority preparatory institute of ideological and political education and other specialized research institutions. Colleges and universities should be encouraged to carry out research on the development of ideological and political education textbooks which is targeted and combined with practice. We should reflect and summarize the experience and lessons of ideological and political education in a timely manner, and actively organize and carry out the teaching practice in the new ideological and political education mode[6].

- We should increase the financial support for the ideological and political education of ethnic preparatory and strengthen the construction of education teachers team $^{[10]}$

\section{CONCLUSION}

Our country is still in the primary stage of socialism. The imbalance of economic and cultural development has made the ideological and political education of the preparatory school have a broad space for development and a considerable vitality. Ideological and political workers in Colleges and universities should seize this opportunity, try to make an effort in basic theory research and teaching practice, and to achieve the self improvement and self transcendence in reform and innovation, and intent to provide enlightenment and guidance for students in ideological and political education.

Under the guidance of adhering to the national theory of Marx, the right way to practice the effectiveness of minority preparatory ideological and political education is to grasp the direction of minority preparatory ideological and political education under the new situation, to set up the education mode to adapt to the new situation, and to take an effective way to carry out all these theories of education reform.

\section{REFERENCES}

[1] Xuesong Zheng, "A Probe into Ethnic Preparatory Education in Qing Dynasty", XUEYUAN ,2013.

[2] State Ethnic Affairs Commission "The Chrestomathy on Central Working Conference about Ethnic Affairs compiled," Beijing, Nationalities Publishing House,P253,1st Edition,04,2015.

[3] Jijuan, "Study on the Management Mechanism of Ideological and Political education for Postgraduates under the New Situation ", Guide to Business,2013.

[4] Wenyu Zheng, "On the particularity and Countermeasures of Ideological and Political Education for Ethnic Minority Preparatory Students", , journal of aba teachers college, 2013.

[5] Junqing Huang, "Research on the Countermeasures of Ideological and Political Education in Ethnic Preparatory College ”, New Western,2012.

[6] Leri Bao, "Review and Reflection on the Policy of Ethnic Preparatory Education Since the Founding of the People's Republic of China", Research On Higher Education Of Nationalities, 2013.

[7] Jun Li, "On the Development, Significance and Nature of the National Ethnic Preparatory Education in China”, Research On Higher Education Of Nationalities,2013. 
[8] Fei Yang, "On the Challenges and Countermeasures of Contemporary College Students' Ideological and Political Education", Theory Research,2015.

[9] Gang Wang, "On the Methods of Improving the Development of Ideological and Political Education in the New Period", Journal of Social Science of Jiamusi University, 2015.

[10] Deng Tu, "An Innovative Research on the National Unity Education of Ethnic Minority Preparatory Students,",Journal of Southwest University for Nationalities ,2011. 